\title{
PHYSICAL AND CHEMICAL VARIABLES, SPECIES COMPOSITION AND COVERAGE OF MACROPHYTES IN PONDS (CASE STUDY IN EASTERN POLAND)
}

\author{
GRZYWNA, A. ${ }^{1}$ - SENDER, J. ${ }^{2 *}-$ BRONOWICKA-MIELNICZUK, U. ${ }^{3}$ \\ ${ }^{1}$ Department of Environmental Engineering and Geodesy, University of Life Sciences in Lublin, \\ Leszczyńskiego 7 Str, 20-069 Lublin, Poland \\ ${ }^{2}$ Department of Hydrobiology and Protection of Ecosystems, University of Life Sciences in \\ Lublin, Dobrzańskiego 37 Str, 20-262 Lublin, Poland \\ ${ }^{3}$ Department of Applied Mathematics and Computer Science, University of Life Sciences in \\ Lublin Gtęboka 28 Str, 20-612 Lublin, Poland \\ *Corresponding author \\ e-mail: joanna.sender@up.lublin.pl; phone/fax: +48-81-461-0061 \\ (Received $18^{\text {th }}$ Dec 2017; accepted $7^{\text {th }}$ Mar 2018)
}

\begin{abstract}
Studies were conducted on the eleven largest and oldest ponds in the mesoregion Western Polesie in Eastern Poland. The aim of the study was to analyze the influence of environmental variables on species richness and vegetation cover of ponds. The analyzed variables included hydraulic parameters of ponds, water quality and buffer zone management. Detrended correspondence analysis (DCA), principal component analysis (PCA) and redundancy analysis (RDA) were applied to reveal principal variation patterns within the data. There were a different number of species comprising the phytolittoral zone in the investigated ponds. This study also showed that ponds are valuable for plant biodiversity. In total 75 species of plants occurred in the studied complex. The total number of species ranged from 10 to 49 in pond. The water of the ponds is characterized by very low value for most tested water quality indicators. The ponds are characterized by statistically significant differences of the buffer zone management. They have similar environmental conditions (temporariness of flooding period, low depth, water quality) and they potentially can share similar species. Our results also showed that the relationships between macrophyte species and cover depends on buffer zone management and some physicochemical variables of water.
\end{abstract}

Keywords: water body, plant community, water quality, buffer zone management, ordination methods

\section{Introduction}

Owing to their important contribution to aquatic biodiversity, ponds should be considered as an important target system in strategic plans that aim at conserving or developing aquatic biodiversity at the landscape scale. Such plans can only be effective if based on a solid knowledge of the factors that affect pond community structure and diversity. In issue, several studies document clear associations between the aquatic community characteristics and a variety of ecologically relevant, such as hydroperiod (Della Bella et al., 2008), surface area (Céréghino et al., 2008a), salinity and pond connectivity (Oertli et al., 2007; Boix et al., 2008; Gascón et al., 2008). In the first European Pond Workshop devoted to the Conservation and Monitoring of Pond Biodiversity launched a European network of people and institutions to collaboratively work on solving fundamental scientific issues and developing practical applications to protect ponds (Heino et al., 2015). 
Ponds, particularly temporary ones, are aquatic habitats with multiple constraints due to their great abiotic spatial variability. However, this abiotic variability can provide certain, well adapted species, advanced opportunities to succeed (Lemmens et al., 2013). Drought is the principal constraint limiting macrophytes development and establishment in ponds. This constraint is even greater because of its unpredictability and alternation of dry and wet phase varies (Della Bella et al., 2008). The development of life cycles with different length, the dominance of one form of reproduction, the major or minor investment in seed production and the germination patterns, might concur in structuring the macrophyte assemblages in wetlands with different hydroperiod length (Ierotheos et al., 2010).

Research, driven both by the need to improve pond conservation strategies and by increasing interest in fundamental aspects of pond ecology (Heino et al., 2015), has started to shed new light on pond ecosystem structure and function. As a result, there is growing evidence that ponds are functionally different from larger lakes (Bornette et al., 2011) and that despite their small size they are collectively biologically diverse (Ierotheos et al., 2010). Ponds also show greater biotic and environmental temporal amplitudes than rivers and lakes (Céréghino et al., 2008b; Søndergaard et al., 2010).

In the mesoregion Western Polesie several pond complexes exist among which are the Sosnowica and Libiszów pond complexes. These pond complexes have been altered for harbouring and breeding carp. From an economic point of view, eutrophication is beneficial as it stimulates the growth of organisms that serve as the base of the food chain for fish. Hypertrophy is an adverse phenomenon resulting from over-fertilizing of ponds. In addition the data generated, so that this information may be used as the decision maker for conservation and effective utilization of water bodies particularly the reservoirs (Grzywna, 2013).

Studies were conducted on the eleven largest and oldest ponds in this region. They have been for one fish farming since World War I (Grzywna and Nieścioruk, 2016). The aim of the study was to evaluate the richness and distribution of aquatic macrophytes in fishing farm and to examine the relationships between habitat characteristics, environmental conditions, and aquatic macrophyte compositions. The ponds were all located within the border parts of protected natural areas of the Natura 2000 zone - the Forest of Parczew PLB060006. Data concerning physical and chemical properties of water, as well morphology, landscape and macrophytes were collected.

The aim of the study was to analyze the influence of environmental variables on species richness and vegetation cover of ponds. The analyzed variables included hydraulic parameters of ponds, water quality and buffer zone management. Hydraulic parameters of ponds were characterized by 2 values. Water quality was determined based on 10 physical and chemical properties of water. Five ways of using the buffer zone were identified.

\section{Materials and methods}

The paper presents the results of water quality tests, buffer zone management and richness of macrophyte species. Studies were carried out in July 2016 in two pond complexes in Western Polesie (Eastern Poland). The first complex, Sosnowica, consists of 6 fish ponds located in the Piwonia river basin $\left(51^{\circ} 30^{\prime} \mathrm{N}, 23^{\circ} 05^{\prime} \mathrm{E}\right)$. The second complex, Libiszów, consists of 5 fish ponds located in the Konotopa river basin $\left(51^{\circ} 40^{\prime} \mathrm{N}, 22^{\circ} 50^{\prime} \mathrm{E}\right)$. Both ponds in spring time are filled with water from the Wieprz 
and Krzna Canal (Fig. 1). They were all shallow with a different water area - WA, and depth - D (Table 1). The three largest ponds in each of the investigated complexes were flowing ponds connected by a system of ditches with the river Piwonia and river Konotopa. The rest of the studied ponds were standing ponds. All the studied ponds were temporary, having shorter wet-phase duration $<200$ days. The ordination analysis covered 75 species, 11 study sites and 17 environmental variables.

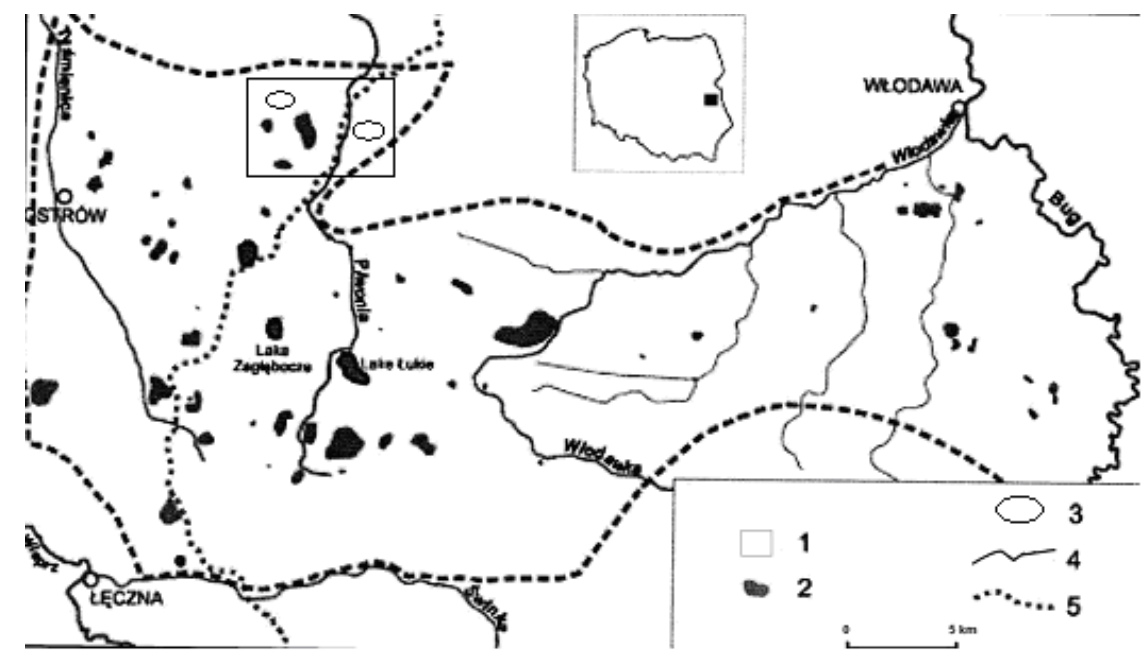

Figure 1. Location of the study area in the Western Polesie. 1 - study area, 2 -lakes, 3 ponds, 4 - river, 5 - Wieprz-Krzna Canal

Minimum and maximum water depth was measured in situ using a meter stick. Pond area, water surface and buffer zone management (BZM) were estimated using orthoimage interpretation. Detailed analysis of land use types were carried out in ponds buffer zones, assuming the same radius length for ponds, $100 \mathrm{~m}$, measured from the centroid of ponds and set automatically by the ArcGIS 10.0 software. Five ways of using the buffer zone were identified - Infrastructure (I), Water surface (W), Grasslands $(\mathrm{G})$, Forests (F), Bushes (B).

Table 1. Hydraulic parameters of ponds

\begin{tabular}{c|c|c|c|c|c|c}
\hline $\begin{array}{c}\text { No. } \\
\text { ponds }\end{array}$ & Name of pond & $\begin{array}{c}\text { Total area } \\
\text { (ha) }\end{array}$ & $\begin{array}{c}\text { Water } \\
\text { area (ha) }\end{array}$ & $\begin{array}{c}\text { Depth } \\
\text { min-max (m) }\end{array}$ & $\begin{array}{c}\text { Volume of the } \\
\text { water }\left(\mathbf{m}^{\mathbf{3}}\right)\end{array}$ & Power supply \\
\hline 1 & Hetman & 90 & 54.5 & $0.8-1.2$ & 530 & Flowing pond \\
2 & Anielski & 83 & 44.7 & $0.8-1.2$ & 440 & Flowing pond \\
3 & Kłoda & 64 & 31.6 & $0.6-1.0$ & 250 & Flowing pond \\
4 & Jedlina & 41.5 & 30.4 & $1.0-1.5$ & 360 & Standing pond \\
5 & Renta & 15.5 & 13.3 & $0.7-1.2$ & 120 & Standing pond \\
6 & Rumieniec & 34 & 25.7 & $0.7-1.2$ & 230 & Flowing pond \\
7 & Płonne & 37 & 28.6 & $0.5-0.9$ & 220 & Flowing pond \\
8 & Wiklik & 40 & 30.8 & $0.8-1.2$ & 300 & Flowing pond \\
9 & Morski & 35 & 29.5 & $0.6-1.0$ & 240 & Standing pond \\
10 & Kościuszko & 27 & 23.8 & $0.6-1.0$ & 190 & Standing pond \\
11 & Racławice & 24 & 19.5 & $0.6-1.0$ & 150 & Standing pond \\
\hline
\end{tabular}


Conductivity (Con), dissolved oxygen (DO) and $\mathrm{pH}$ were measured in situ with a multi-parameter probe. Three subsamples were taken and preserved at $4{ }^{\circ} \mathrm{C}$ to be analyzed in the laboratory later. Two of the subsamples were glass filtered to determine chlorides $(\mathrm{Cl})$, sulphates $\left(\mathrm{SO}_{4}\right)$, nitrate nitrogen $\left(\mathrm{N}-\mathrm{NO}_{3}\right)$ and ammonia nitrogen $(\mathrm{N}-$ $\mathrm{NH}_{4}$ ). The third subsample, which was unfiltered, was used to determine total phosphorus (TP) and total nitrogen (TN). Water transparency was measured by visual evaluation Secchi disc (SD) (Grzywna et al., 2015).

Total surface covered with all studied groups of plants was calculated on the basis of macrophyte analysis in horizontal transects, extending from the edge of the embankment of the pond to the maximum colonization depth in pond. Aquatic transects radiated inward towards the centre of the pond for the length of macrophyte occurrence and were uniformly distributed along the entire shoreline every $100 \mathrm{~m}$. The spatial structure of macrophytes was analysed in detail from 9 (the smallest pond) to 25 (the biggest pond) transects within the each pond. In each transect we collected emergent macrophytes using frames with sampling area of $0.5 \mathrm{~m}^{2}$. Each measurement was repeated five times. Submerged and floating leaves macrophytes were sampled using a floristic Bernatowicz type of sampler (area $0.16 \mathrm{~m}^{2}$ ) (Sender, 2016). On this basis, we determined species composition and the range of occurrence of particular groups of macrophytes in ponds. We recorded all species among 4 groups of macrophytes (emergent - EM, submerged - SM, floating - FM and flood meadow taxa-MT).

To calculate the present proportion of the different plant groups in ponds ArcGIS 10.0 software was used. Total coverage and range of particular groups of plants occurrence was done by a retrospective photointerpretative analysis (Chmielewski et al., 1996) using orthophotomap (2013), bathymetry maps of ponds, as well as field investigations. Maximum depth and GPS location were determined using the sonar Elite no. 5 of LOWRENCE. Aquatic plants were grouped in five class of coverage $(1=1-$ $5 \%, 2=5-25 \%, 3=26-50 \%, 4=51-75 \%$ and $5=76-100 \%$ ), following the phytosociologic approach (Braun-Blanquet, 1976). Phytosociological units were distinguished using a systematic and nomenclature system by Matuszkiewicz (2008).

The data set was first subjected to detrended correspondence analysis (DCA) which showed a first-axis gradient length of 0.68 in standard deviation units. Therefore we decided to apply linear methods of ordination as principal component analysis (PCA) and redundancy analysis (RDA). PCA with standardized environmental variables was used to visualize patterns of environmental variation across ponds. Prior to the analysis, redundant environmental variables (with linear correlation coefficient $r>0.7$ ) were omitted to avoid collinear rite (Blanchet et al., 2008). Further analysis took the following environmental variables into account: W, G, F (buffer zone management); TN, TP and Con (water quality). Significant PCA axes were selected with both KaiserGutman criterion and the broken-stick model (Borcard et al., 2011). In the next stage, redundancy analyses with forward selection were performed. We carried out an RDA with all environmental explanatory variables, as well as for two subsets of variables (BZM and plant cover). We decided to apply Hellinger transformation to the species data (Legendre and Gallagher, 2001). Environmental data was cube root transformed and standarized to fulfill the assumption of normality. The RDA results were used to produce an ordination triplot. Statistical analyses were performed using vegan package in R (R Core Team, 2015; Oksanen et al., 2016). 


\section{Results}

The water of the ponds is characterized by very low value for most studied water quality indicators. It applies mainly concentrations of such indicators as: $\mathrm{Cl}, \mathrm{SO}_{4}, \mathrm{~N}-$ $\mathrm{NO}_{3}, \mathrm{~N}-\mathrm{NH}_{4}$, conductivity (con.), water reaction ( $\mathrm{pH}$ ), as well as $\mathrm{TN}$. The concentration of DO and TP were different and rather high in studied ponds. The DO concentration reached average value $2.3 \mathrm{mgO}_{2} \cdot \mathrm{dm}^{-3}$ (range from 1.9 to $2.8 \mathrm{mgO}_{2} \cdot \mathrm{dm}^{-3}$ ), while, TP concentration ranged from 0.62 to $4.35 \mathrm{mgP} \cdot \mathrm{dm}^{-3}$ (Table 2).

Statistically insignificant differences in physical and chemical parameters of water are characteristic of the analyzed ponds.

The ponds are characterized by statistically significant differences of the buffer zone management. The zone is predominantly overgrown with forests and bushes (accounting for $>50 \%$ of the total area). In the case of ponds situated in the central part of the complexes the water of the neighbouring ponds constitutes more than $40 \%$ of the ecotone area (Table 3).

Table 2. Physical-chemical variables of water in ponds

\begin{tabular}{c|c|c|c|c|c|c|c|c|c|c|c|c}
\hline Feature & UnitlPond & $\mathbf{1}$ & $\mathbf{2}$ & $\mathbf{3}$ & $\mathbf{4}$ & $\mathbf{5}$ & $\mathbf{6}$ & $\mathbf{7}$ & $\mathbf{8}$ & $\mathbf{9}$ & $\mathbf{1 0}$ & $\mathbf{1 1}$ \\
\hline $\mathrm{SD}$ & $\mathrm{m}$ & 0.7 & 0.7 & 0.7 & 0.4 & 0.3 & 0.5 & 0.6 & 0.5 & 0.5 & 0.4 & 0.5 \\
$\mathrm{pH}$ & & 7.1 & 6.9 & 6.9 & 7 & 7.1 & 7.4 & 7.3 & 7.7 & 8.2 & 8 & 7.6 \\
$\mathrm{DO}$ & $\mathrm{mgO}_{2} \cdot \mathrm{dm}^{-3}$ & 2.5 & 2.3 & 2.0 & 1.9 & 2.6 & 2.1 & 2.8 & 2.5 & 2.7 & 2.8 & 2.4 \\
$\mathrm{Con}$ & $\mu \mathrm{S} \cdot \mathrm{cm}^{-1}$ & 389 & 209 & 237 & 220 & 302 & 360 & 370 & 380 & 300 & 340 & 321 \\
$\mathrm{~N}^{-N_{4}}$ & $\mathrm{mg} \cdot \mathrm{dm}^{-3}$ & 0.45 & 0.09 & 0.11 & 0.08 & 0.06 & 0.37 & 0.29 & 0.22 & 0.17 & 0.25 & 0.3 \\
$\mathrm{~N}^{-} \mathrm{NO}_{3}$ & $\mathrm{mg} \cdot \mathrm{dm}^{-3}$ & 0.46 & 0.65 & 0.48 & 0.6 & 0.61 & 0.5 & 0.53 & 0.55 & 0.59 & 0.51 & 0.6 \\
$\mathrm{TN}$ & $\mathrm{mg} \cdot \mathrm{dm}^{-3}$ & 1.4 & 0.5 & 0.9 & 0.6 & 0.9 & 0.97 & 0.82 & 0.93 & 0.61 & 0.55 & 0.8 \\
$\mathrm{TP}$ & $\mathrm{mg} \cdot \mathrm{dm}^{-3}$ & 0.62 & 1.88 & 2.77 & 4.35 & 0.84 & 1.98 & 1.67 & 1.82 & 1.24 & 1.11 & 1.5 \\
$\mathrm{SO}_{4}$ & $\mathrm{mg} \cdot \mathrm{dm}^{-3}$ & 25 & 30 & 32 & 21 & 69 & 27 & 24 & 20 & 31 & 33 & 40 \\
$\mathrm{Cl}$ & $\mathrm{mg} \cdot \mathrm{dm}^{-3}$ & 18 & 16 & 14 & 12 & 4 & 13 & 11 & 10 & 8 & 7 & 15 \\
\hline
\end{tabular}

Table 3. Buffer zone management

\begin{tabular}{c|c|c|c|c|c|c|c|c|c|c|c}
\hline Land use [\%] & $\mathbf{1}$ & $\mathbf{2}$ & $\mathbf{3}$ & $\mathbf{4}$ & $\mathbf{5}$ & $\mathbf{6}$ & $\mathbf{7}$ & $\mathbf{8}$ & $\mathbf{9}$ & $\mathbf{1 0}$ & $\mathbf{1 1}$ \\
\hline Infrastructure (I) & 8 & 2 & 3 & 1 & 0 & 3 & 12 & 10 & 1 & 3 & 1 \\
Water (W) & 40 & 31 & 7 & 19 & 14 & 0 & 0 & 0 & 45 & 40 & 26 \\
Grasslands (G) & 3 & 0 & 5 & 10 & 1 & 12 & 20 & 18 & 10 & 5 & 7 \\
Bushes (B) & 29 & 59 & 60 & 37 & 19 & 25 & 18 & 9 & 4 & 7 & 18 \\
Forest (F) & 20 & 8 & 25 & 33 & 66 & 60 & 50 & 63 & 30 & 45 & 48 \\
\hline
\end{tabular}

Distribution of plants in the ponds was heterogeneous (mosaic). Phytolittoral zones often developed from one bank to another. Four different growth groups of macrophytes were found: submerged, emergent, floating and flood-meadow taxa. In total, 75 species of plants occurred in the studied complex. The number of species ranged from 10 in Morski pond to 49 in Anielski pond. There was a different number of species comprising the phytolittoral zone in the investigated ponds. The most abundant aquatic plant species found in the ponds were flood-meadow species (Table 4). They were represented by 49 (up to 67\%) of aquatic species in some ponds. The species richness of 
the pond was up 6 to 34 species. The most common species were: Bidens trpartita, Lycopus europaeus, Scirpus sylvaticus. They overgrow the embankment area, beyond the permanent water surface. Emergent macrophytes (EM) were represented by 10 species, occurring in all ponds. The dominant species among emergent macrophytes were Phragmites australis and Typha angustifolia. Submerged macrophytes (SM) comprised the poorest group, representing only 7 species. Species of this group occur in only 6 ponds. The most common species of SM was Ceratophyllum demersum. Floating macrophytes (FM) were represented by 9 species occurring in 9 ponds. The species richness of the pond was up to 5 species. The most common FM species were: Lemna minor i Polygonum amphbium. Among the species present in the investigated ponds were protected ones including: Nuphar lutea, and Nymphea alba. The total pond area covered with vegetation ranged from 5.0 to $39.6 \%$.

Table 4. Characteristic of the macrophytes occurrence

\begin{tabular}{c|c|c|c|c|c|c|c|c|c|c|c}
\hline Pond & $\mathbf{1}$ & $\mathbf{2}$ & $\mathbf{3}$ & $\mathbf{4}$ & $\mathbf{5}$ & $\mathbf{6}$ & $\mathbf{7}$ & $\mathbf{8}$ & $\mathbf{9}$ & $\mathbf{1 0}$ & $\mathbf{1 1}$ \\
\hline \multicolumn{10}{c}{ Macrophyte cover [\%] } \\
\hline Floating & 2.7 & 8.9 & 3.7 & 0 & 1.0 & 1.9 & 0.4 & 0 & 0.4 & 0 & 0.5 \\
Submerged & 2.2 & 3.2 & 3.9 & 0 & 0 & 2.8 & 4.9 & 4.4 & 0 & 0 & 0 \\
Emergent & 5.4 & 13.2 & 12.1 & 5.0 & 2.2 & 4.3 & 5.2 & 7.4 & 3.2 & 2.1 & 1.1 \\
Flood-meadows & 9.2 & 4.7 & 19.9 & 6.9 & 2.6 & 4 & 3.2 & 2.3 & 2.3 & 3.1 & 3.4 \\
Total cover & 19.5 & 30 & 39.6 & 11.9 & 5.8 & 13 & 13.4 & 14.1 & 5.9 & 5.2 & 5.0 \\
\hline \multicolumn{10}{|c|}{ Species number } \\
\hline Floating & 2 & 6 & 7 & 0 & 3 & 3 & 1 & 0 & 2 & 0 & 2 \\
Submerged & 0 & 2 & 3 & 0 & 0 & 3 & 3 & 3 & 0 & 0 & 0 \\
Emergent & 7 & 7 & 6 & 3 & 3 & 5 & 2 & 3 & 2 & 4 & 4 \\
Flood-meadows & 25 & 34 & 22 & 10 & 12 & 20 & 17 & 15 & 9 & 6 & 12 \\
Total number & 35 & 49 & 38 & 13 & 18 & 31 & 23 & 22 & 13 & 10 & 18 \\
\hline
\end{tabular}

PCA axes 1 and 2 explained $72.06 \%$ of a total variance (Fig. 2). Axis 1 explained $48.55 \%$ of the total variance with forest and grassland coverage and conductivity showing high positive loading $(\lambda=1.04, \lambda=0.81, \lambda=0.77$, respectively) and total phosphorus and total nitrogen showing a negative loadings $(\lambda=0.75, \lambda=0.71$, respectively). Axis 2 explained $23.52 \%$ of the total variance and showed high negative loading for water coverage $(\lambda=-0.87)$ and a positive loading of total nitrogen $(\lambda=0.73)$. Forest coverage and conductivity are highly positively correlated. Water and grassland coverage are negatively correlated. Total nitrogen and water coverage have nearly orthogonal arrows, indicating a correlation close to 0 .

Redundancy analysis results are visualized in an ordination diagram (Fig. 3). All environmental variables explained $76.28 \%$ of the total variation (Legendre and Birks, 2012). The first two RDA axes explained $35.58 \%$ of the total variation in the species data $($ RDA1 $=18.8 \%$, RDA2 $=16.78 \%)$. We performed a statistical significance test using the anova function in the vegan package for all variables and received a significant result $(\mathrm{p}=0.039)$. The results of the forward selection and permutation tests indicated that only total phosphorus are significantly related to the species data $\left(\mathrm{p}=0.02 ; \mathrm{R}^{2}=0.67\right)$. When the subset of variables related to plant cover was considered, a total inertia of $26.85 \%$ was explained $\left(p=0.03 ; R^{2}=0.29\right)$. After the 
forward selection procedure the variable total phosphorus was selected as significant. However, when the subset BZM of environmental variables were taken into account, the explained total inertia was slight $(34.87 \%)$ and not significant $(p=0.105$; $\mathrm{R}^{2}=0.35$ ). Among the strongest species-environment associations, we found that the species Iris pseudoacorus was positively associated with total phosphorus. Typha angustifolia and Eupatorium cannabinum were negatively associated to total phosphorus. Variable total phosphorus seemed to be associated to the negative part of Axis 1.

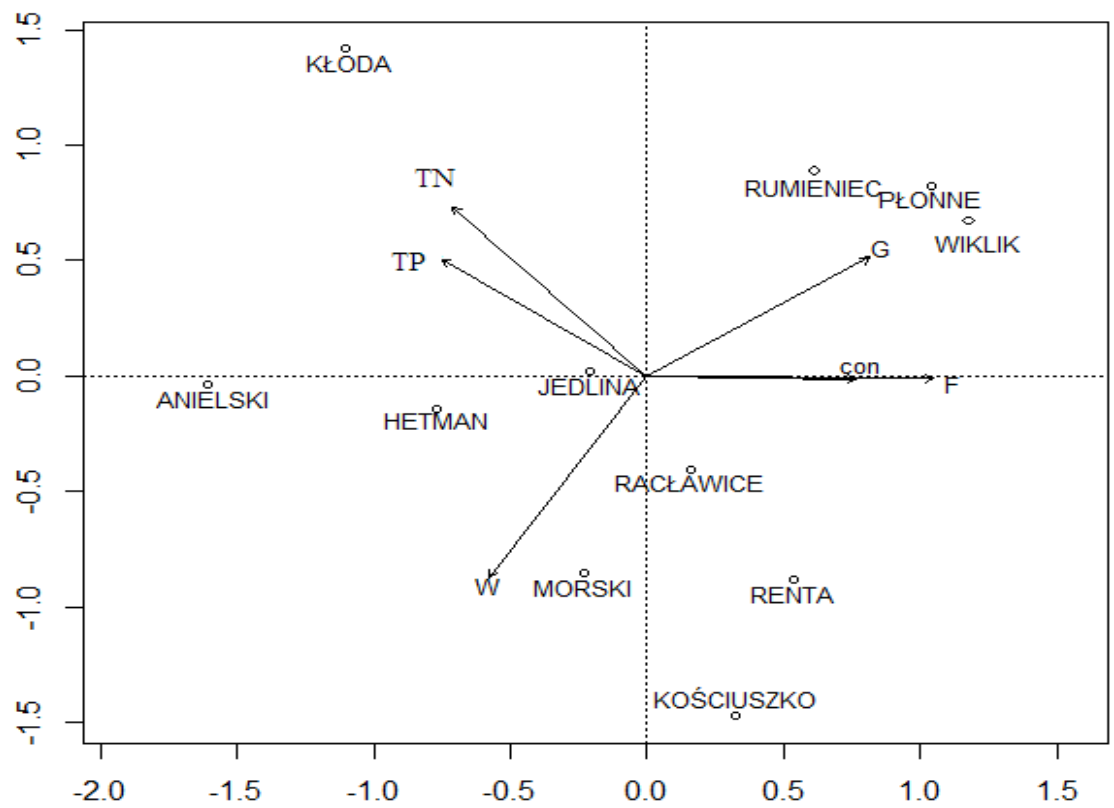

Figure 2. Principal components analysis (PCA) of the environmental variables included in the study and ordination of the sites

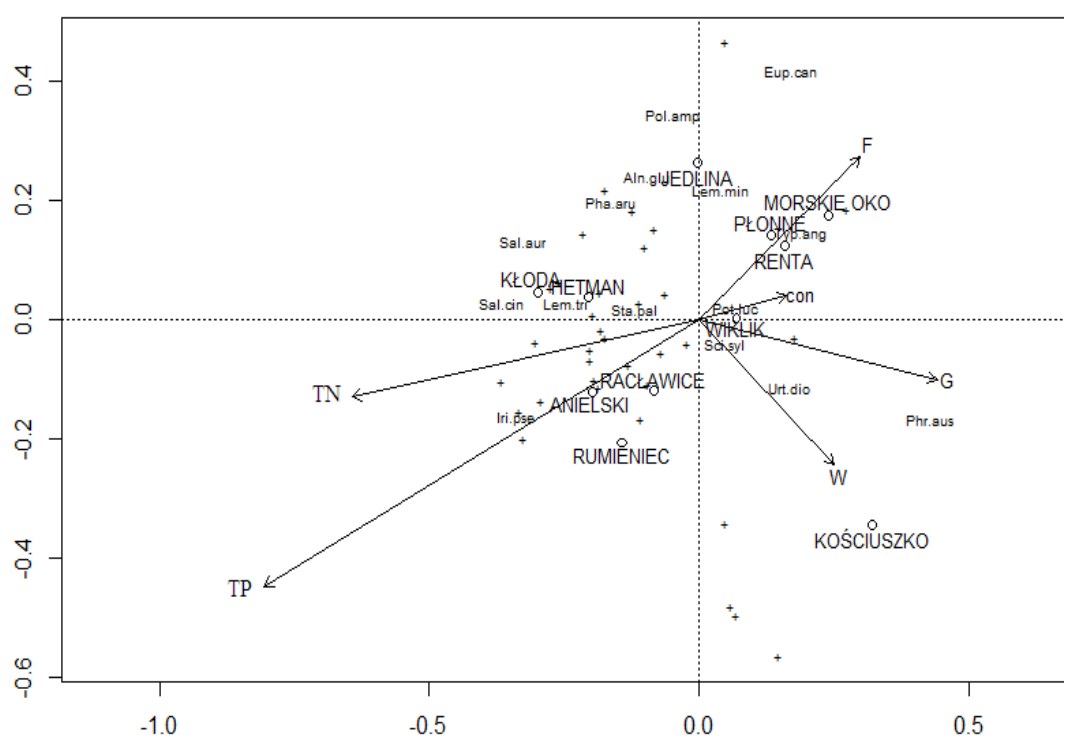

Figure 3. RDA ordination diagram of the environmental variables was included in the study and the sites. All species were included in the analysis, but for clarity the most poorly represented species were displayed on scatter plots as "+" 


\section{Discussion}

Biodiversity in ponds is frequently studied because ponds are rich in microhabitats (Céréghino et al., 2008a) and provide appropriate conditions for aquatic vegetation development and establishment. Specifically, occasional breaks in the surrounding canopy on pond banks create changes in sediment properties that foster the development of plants (Gallego et al., 2014; Gallego et al., 2015).

Ordination analysis included 11 study fish ponds and 17 environmental variables. This study also showed that ponds are valuable for plant biodiversity. In total 75 species of plants occurred in the studied complex. The total number of species ranged from 10 in Morski pond to 49 in Anielski pond. In the studied ponds, a high number of aquatic plants were found according to the most recent works in Europe. In the studied ponds in the Mediterranean there were 51 species (on average 24 species per pond). In a study of lowland ponds in Great Britain an average number of 6 species in standing ponds and 11 species in flowing ponds was recorded and in ponds located in central Italy the average was 9 species (Della Bella et al., 2008; Gallego et al., 2014).

Maintaining the greatest diversity of macrophytes, as well as stable quality water, provides high economic effects in the studied ponds (Lemmens et al., 2013). Landscape characteristics mainly played an important role in species composition-environmental conditions relationships, ale chemical characteristics were significant (Hrivnák et al., 2013). The chemical parameters of the water to a large degree determine the occurrence of macrophytes; however, this is not the only type of pressure. Also, the development of the catchment area and of the littoral zone of the aquatic ecosystems has a significant effect on water and rush plant communities. Studies on the effect of the method of development of the littoral zone of lakes in the state of Wisconsin show that housing development definitely has a negative effect on submerged and floating-leaf plants. Such an effect was not observed for emergent vegetation. On the other hand, a lower share of forests in the catchment basin reduced the development of all macrophyte groups (Ahrenstarff et al., 2009; Akasaka et al., 2010).

The results of the forward selection tests indicated that only floating leaves are significantly related to the cover. They cover the water's surface and in this way provide fish the benefits of shade, protection and breeding areas. Ponds as a rule are shallow and during the summer their temperature rises very fast. This could cause a rapid increase in algal (Lin-lin et al., 2012). The proper buffer zone management (forest mixed meadow) could limit the penetration of sunlight (Sender, 2016). In these places, where the buffer zone is without shading vegetation, they cool the water for the fish and give fish a place to hide. But they could decrease the occurrence of submerged macrophytes. Submerged macrophytes, in the investigated ponds, were not numerous. So, in our opinion a compensation phenomenon appeared in these ponds, like in the shallow lakes from the Polesie region (Sender et al., 2015). Floating leaves may grow well in water with low transparency, well sunlit (Feldmann and Nöges, 2007), so it seems that ponds create the best habitat for them. The litoral and especially the zone of floating leaved plants decrease with increasing lake area due to wind stress related to the height and strength of waves (Feldmann, 2012; Kolada, 2014).

Ponds are ecosystems created by man and like each type of such ecosystem they require man's constant interference (regulation of water level, feeding fish). They are usually formed in unattractive agricultural places, while their presence significantly increases the natural values of the area. Antrophogenic waters provide suitable environmental conditions for the potential establishment and growth of macrophytes, 
floating-leaved and flood-meadow taxa. The analysed ponds could be an excellent example of sustainable development.

\section{Conclusions}

In conclusion, this study highlighted that temporary ponds in Western Polesie have different macrophyte species composition, with aquatic species exclusively found in each pond. Temporary ponds, while capable of hosting some hydrophytes, are tightly linked to humid meadows. They have similar environmental conditions (temporariness of flooding period, low depth, water quality) and they potentially can share similar species. Our results also showed that the relationships between macrophyte species and cover depends on buffer zone management and some physico-chemical variables of water. The PCA analysis showed a positive effect of the presence of grassland and forests in the buffer zone on the diversification of plant vegetation. We observe a negative effect on the diversity of vegetation in the case of high concentration of nitrogen and total phosphorus and increasing surface of the ponds. The RDA analysis showed a statistically significant negative effect of the total phosphorus concentration on macrophyte differentiation.

For conservation purposes, the studied temporary ponds hosted some species of conservation interest at regional scale: Nuphar lutea, Nymphea alba and Epipactis palustris (Lower Risk Category) are exclusively found more than in only one of pond. Therefore, the ponds should be preserved or created because both could give an irreplaceable contribution to the conservation of aquatic plant diversity of small water bodies.

Studies on physical and chemical parameters and occurrence of aquatic vegetation should be carried out in subsequent years at different times of the year. These factors are subject to seasonal and long-term changes. In the future, these studies will allow to determine the directions of changes and their causes.

\section{REFERENCES}

[1] Ahrenstorff, T. D., Sass, G. G., Helmus, M. R. (2009): The influence of littoral zone coarse woody habitat on home range size, spatial distribution, and feeding ecology of largemouth bass (Micropterus salmoides). - Hydrobiologia 623: 223-233.

[2] Akasaka, M., Takamura, N., Mitsuhashi, H., Kadono, Y. (2010): Effects of land use on aquatic macrophyte diversity and water quality of ponds. - Freshwater Biology 55: 909922.

[3] Blanchet, F. G., Legendre, P., Borcard, D. (2008): Forward selection of explanatory variables. - Ecology 89: 2623-2632.

[4] Boix, D., Gascón, S., Sala, J., Badosa, A., Brucet, S., López-Flores, R., Martinoy, M., Gifre, J., Quintana, X. D. (2008): Patterns of composition and species richness of crustaceans and aquatic insects along environmental gradients in Mediterranean water bodies. - Hydrobiologia 597: 53-69.

[5] Borcard, D., Gillet, F., Legendre, P. (2011): Numerical Ecology with R. - Springer, New York.

[6] Bornette, G., Puijalon, S. (2011): Response of aquatic plants to abiotic factors: a review. - Aquatic Science 73: 1-14.

[7] Braun-Blanquet, J. (1976): Pflanzensoziologie. 3 Aufl. - Springer, Vienna. 
[8] Céréghino, R., Biggs, J., Oertli, B., Declerck, S. (2008a): The ecology of European ponds: defining the characteristics of a neglected freshwater habitat. - Hydrobiologia 597: $1-6$.

[9] Céréghino, R., Ruggiero, A., Marty, P., Ange'libert, S. (2008b): Biodiversity and distribution patterns of freshwater invertebrates in farm ponds of a southwestern French agricultural landscape. - Hydrobiologia 597: 43-51.

[10] Chmielewski, T. J., Olenderek, H. Sielewicz, B. (1996): Retrospective Analysis of Changes in Ecological Structure Kampinos National Park in the Last 40-Year Period (in Polish). - In: Kistowski, M. (ed.) Ecological and Landscape Studies in Protected Areas, pp. 125-129. Uniwersytet Gdański, Polska Asocjacja Ekologii Krajobrazu, Gdańsk (in Polish).

[11] Della Bella, V., Bazzanti, M., Dowgiallo, M. G., Iberite, M. (2008): Macropyte diversity and physico-chemical characteristics of Tyrrhenian coast ponds in central Italy: implications for conservation. - Hydrobiologia: 597: 85-95.

[12] Feldmann, T. (2012): The structuring role of lake conditions for aquatic macrophytes. A thesis for applying for the degree of doctor of Philosophy in Hydrobiology. - Estonian University of Life Sciences, Tartu.

[13] Feldmann, T., Nöges, P. (2007): Factors controlling macrophyte distribution in large shallow Lake Vortsjarv. - Aquatic Botany 87: 15-21.

[14] Gallego, I., Davidson, T. A., Jeppesen, E., Perez-Martınez, C., Fuentes-Rodriguez, F., Juan, M., Casas, J. J. (2014). Disturbance from pond management obscures local and regional drivers of assemblages of primary producers. - Freshwater Biology 59: 14061422.

[15] Gallego, I., Perez-Martınez, C., Sanchez-Castillo, P. M., Fuentes-Rodrıguez, F., Juan, M., Casas, J. J. (2015): Physical, chemical, and management-related drivers of submerged macrophyte occurrence in Mediterranean farm ponds. - Hydrobiologia 762: 209-222.

[16] Gascón, S., Boix, D., Sala, J., Quintana, X. D. (2008): Relation between macro invertebrate life strategies and habitat traits in Mediterranean salt marsh ponds (Empordà wetlands, NE Iberian Peninsula). - Hydrobiologia 597: 71-83.

[17] Grzywna, A. (2013): Transformation of hydrographic network in the basin ponds Sosnowica. - Acta Scientiarum Polonorum-Formatio Circumiectus 12(4): 67-73 (in Polish).

[18] Grzywna, A., Nieścioruk, K. (2016): Changes of hydrographic network of Uściwierskie Lowering according to cartographic materials. - Journal of Ecological Engineering 17(4): $148-153$.

[19] Grzywna, A., Tarkowska-Kukuryk, M., Bochniak, A., Marczuk, A., Jóźwiakowski, K., Marzec, M., Mazur, A., Obroślak, R., Nieścioruk, K., Zarajczyk, J. (2015): Application of chemical and biological indicators for assessment of an ecological potential of artificial watercourses. - Przemysł Chemiczny 94(11): 1954-1957 (in Polish).

[20] Heino, J., Melo, A. S., Siqueira, T., Soininen, J., Valanko, S., Bini, L. M. (2015): Metacommunity organisation, spatial extent and dispersal in aquatic systems: patterns, processes and prospects. - Freshwater Biology 60: 845-869.

[21] Hrivnák, R., Ot’ahel'ová, H., Kochjarová, J., Pal'ove-Balang, P. (2013): Effect of environmental conditions on species composition of macrophytes - study from two distinct biogeographical regions of Central Europe. - Knowledge and Management of Aquatic Ecosystems 411: 9-19.

[22] Ierotheos, Z., Miltiadis, Z. (2010): Mediterranean temporary ponds. A disappearing ecosystem. - Biodiversity and Conservation 19: 3827-3834.

[23] Kolada, A. (2014): The effect of lake morphology on aquatic vegetation development and changes under the influence of eutrophication. - Ecological Indicators 38: 282-293.

[24] Legendre, P., Birks, H. J. B. (2012): From Classical to Canonical Ordination. - In: Birks, H. J. B., Lotter, A. F., Juggins, S., Smol, J. P. (eds.) Tracking Environmental Change 
Using Lake Sediments, Vol. 5: Data Handling and Numerical Techniques. Springer, Dordrecht.

[25] Legendre, P., Gallagher, E. D. (2001): Ecologically meaningful transformations for ordination of species data. - Oecologia 129: 271-280.

[26] Lemmens, P., Mergeay, J., De Bie, T., Van Wichelen, J., De Meester, L., Declerck, S. A. J. (2013): How to maximally support local and regional biodiversity in applied conservation? Insights from pond management. - PLoS One 8: e72538.

[27] Lin-lin, C., Guang-wei, Z., Meng-yuan, Z., Hai, X., Bo-qiang, Q. (2012): Effects of temperature and nutrients on phytoplankton biomass during bloom seasons in Taihu Lake. - Water Science and Engineering 5(4): 361-374.

[28] Matuszkiewicz, W. (2008): Guide for the Determination of Plant Communities in Poland. - PWN, Warszawa (in Polish).

[29] Oertli, B., Indermuehle, N., Ange'libert, S., Hinden, H., Stoll, A. (2007): Macroinvertebrate assemblages in 25 high alpine ponds of the Swiss National Park (Cirque of Macun) and relation to environmental variables. - Hydrobiologia 595: 29-41.

[30] Oksanen, J., Blanchet, F. G., Friendly, M., Kindt, R., Legendre, P., Mc Glinn, D., Minchin, P. R., O'Hara, R. B., Simpson, G. L., Solymos, P., Stevens, H. M., Szoecs, E., Wagner, H. (2016): vegan: Community Ecology Package ver. 2.4-1. - CRAN.

[31] R Core Team (2015): R: A language and environment for statistical computing. - $\mathrm{R}$ Foundation for Statistical Computing, Vienna, Austria. http://www.R-project.org/.

[32] Sender, J. (2016): The effect of riparian forest shade on the structural characteristics of macrophytes in a mid-forest lake. - Applied Ecology and Environmental Research 14(3): 249-261.

[33] Sender, J., Kolejko, M., Demetraki-Paleolog, A. (2015): Interactions within macrophytes in some small lakes from Polesie Lubelskie Region. - Teka Komisji Ochrony i Kształtowania Srodowiska Przyrodniczego 12: 102-110.

[34] Søndergaard, M., Johansson, L. S., Lauridsen, T. L., Jørgensen, T. B., Liboriussen, L., Jeppesen, E. (2010): Submerged macrophytes as indicators of the ecological quality of lakes. - Freshwater Biology 55: 893-908. 